Thematic Article

\title{
Use of Electronic Resources in Teaching Religion in Higher Education: Best Practices from the SULSIT, Bulgaria
}

\author{
Svetla Shapkalova ${ }^{1}$, Georgeta Nazarska ${ }^{2}$ \\ Recommended citation: \\ Shapkalova, S., \& Nazarska, G. (2020). Use of electronic resources in teaching religion in higher education: best practices \\ from the SULSIT, Bulgaria. Central European Journal of Educational Research, 2(2), 56-60. \\ https://doi.org/10.37441/CEJER/2020/2/2/7914
}

\begin{abstract}
This paper describes actually methodical attempts to use library electronic resources in academic education. Some opportunities for improving the teaching of religious cultural heritage and for diversify the methods of assessment of students in Bulgarian universities are commented. The text describes the personal experience of the authors with students of 3rd-4th grades from the State University of Library Studies and IT (SULSIT), Bulgaria. Among the "best practices" are tasks of performing on-line survey of digital resources of periodicals from the digital resources of the "St. St. Cyril and Methodius" National Library, of making content analysis of the database on a particular subject, of preparing bibliographic descriptions of the new discovered resources, of writing historical analyses, of generating thematic bibliographies on topics related to religion, using the resources of the electronic catalogs of regional public libraries in the country.
\end{abstract}

Keywords: electronic resources; religious cultural heritage; higher education; Bulgaria; interactive methods of training

\section{Introduction}

The State University of Library Studies and IT (SULSIT) is a secular university in Sofia, Bulgaria, where a specific educational model for teaching religion in the majors "Cultural Heritage", "Information Resources of Tourism", "Archival Studies and Documentary", "Print Communications", and "Library Studies" was created. Among its fundamental principles are "learning by doing" and shaping students' skills and competencies (Beard $\&$ Wilson, 2006). One of the main tools for this is using of IT and electronic resources. They are applied in lectures and extracurricular training, incl. in evaluating students (Nazarska \& Shapkalova, 2015).

\section{Research design and Methods}

This research paper analyses the potential of web-based electronic resources to improve classroom training and to diversify methods for testing and evaluating students' knowledge and skills in secular higher education institutions, and in particular for teaching about cultural heritage.

The topic of the introduction of new information and communication technologies (ICT) into secondary and higher education, incl. going on is not new to scientific literature. Even within the EU, it has become a priority over the last 15 years, being interpreted by educational administrators, pedagogues, information science experts, methodologists, and teachers. It has been thoroughly researched and discussed in the field of higher education with focusing on e-learning, distance learning, opportunities for combining traditional methods with electronic resources (incl. web based and offered by cultural institutions). Although publications on symbiosis of religious education and ICT are few (cf. Beard \& Wilson, 2006; Chryssides, 2013; Jackson, 2014).

\footnotetext{
${ }^{1}$ SULSIT, Sofia, Bulgaria; s.shapkalova@unibit.bg

2 SULSIT, Sofia, Bulgaria; georgeta.nazarska@gmail.com
} 
This research paper describes the methodologically validated experience of authors with students from the SULSIT in the period of 2017-2020. The algorithms and results of three types of tasks are presented and analysed.

\section{Bibliographic reference task on "Religious Books in E-Databases of Bulgarian Regional Libraries"}

The main purposes of public libraries are the collecting, archiving and preservation of the documental heritage. Usually the best library practices are applied in the education of kids, pupils, and students from high schools and universities, and also of adults who would like to improve their knowledge. Public libraries offer free access to different services, which forms users' bibliographic culture and enriches their information literacy (Gorman, 2006, p. 20). A substantial part of the literary cultural heritage of Bulgaria is being preserved in its 27 regional libraries. The Public Libraries Act of 2009 states that the libraries assist the Ministry of Culture to put into practice the state policy of library and information services. Public libraries also develop and participate in programs and projects on further education, cultural integration and the establishment of the different religions dialogue (Zakon, 2009). Recently Bulgarian libraries became modern information centers and their priorities are to implement modern technologies both through constant enrichment of the variety of services for the people and activities to automate and digitize the library processes. Regional libraries also quite successfully coordinate their research activity by sustaining local archives and allowing their public use (Dobreva, 2015).

When we prepared a students' task in 2017/2018 academic year, intending both educational and methodological purposes, we consider the task of libraries to be information centers where readers can access new book resources, the well-organized and preserved regional libraries' collections, as well priority of their activities to provide religious documents for reading (Wilson, 1982).

The subjects of research were books from "Religion. Theology” Main Class №2 of the Universal Decimal Classification (UDC). In library theory and practice it includes the following special auxiliary numbers: $2-1$ Theory and philosophy of religion. Nature of religion. Phenomenon of religion; 2-2 Evidences of religion; 2-3 Persons in religion; 2-4 Religious activities. Religious practice; 2-5 Worship broadly. Cult. Rites and ceremonies; 2-6 Processes in religion; 2-7 Religious organization and administration; 2-8 Religions characterized by various properties; 2-9 History of the faith, religion, denomination or church (McIlwaine, 2009, p. 5432-5439).

Since the 1950s Bulgarian communist authorities strictly "expurgated" religious publications from public library collections. Nowadays such kind of literature of various genre and content is freely available at the bookshops. Public interest in this subject-matter has grown and regional libraries are collecting religious books from all denominations. The books from the Main Class №2 come to the library collections by subscription, purchase or donation. The purchase is according to policy of public libraries and readers' tastes, but donations are subjected to strictly requirements (Mladenova, 2003, p. 121).

In collaboration with Assoc. Prof. Dr. Krassimira Alexandrova - a lecturer of "Bibliography" Course at the SULSIT, we had chosen an interdisciplinary methodology combining teaching of Religion and Bibliography. Students of 3rd grade, studying in "Library Studies" major (full-time and part-time) received a self-directed task to search the electronic catalogs of several regional libraries for available books from "Religion. Theology" Main Class №2 and then to include all searched resources in model bibliographic reference lists.

We formulated some specific methodological tasks: 1. To learn all about software products of each regional library; to acquire skills for searching bibliographic data in electronic catalogs; to learn indexing in "Religion. Theology" Main Class №2; 2. To work with documents by year of publication (until 1990), special auxiliary numbers, language etc.; 3. To practice the classification of 2-1, 2-2, 2-3, 2-4, 2-5, 2-6, 2-7, 2-8, 2-9 of Main Class №2; 4. To prepare a reference list; 5 . To consult themselves with their lecturers and librarians; to develop critical thinking skills by selecting the right titles; 6 . To register all omissions and errors of Main Class №2 in the electronic catalogs made by the specialists of the regional libraries; 7. To write a recommendation for optimization of the catalogues.

As a result of the detailed instructions, given by lecturers in seminars and by e-mail, students had been working with 13 regional libraries' e-catalogues. They had successfully processed many titles and classified them according to special auxiliary numbers of the UDC. We had received 21 reference lists about the resources in Blagoevgrad, Gabrovo, Kardjali, Pleven, Rousse (2 students), Shoumen, Silistra, Smolian, Sofia (2 students), Stara Zagora, Varna, Veliko Tarnovo, and Vidin. 
During the preparation of bibliographic reference lists students encountered some difficulties, but evaluated their self-work task as useful and important for their training. In our opinion, it effected primarily heuristic, as it enabled students to acquire and refine basic skills in working with electronic resources. As future professionals, they must master and successfully use them. In addition, the task made a great contribution to gaining new knowledge of religion and identifying its connection with bibliographic science.

\section{Searching of publications in electronic library catalogue and composing of thematic bibliography}

In the 2018/2019 academic year, the students of 3rd-4th grades, attending the "Information Resources of Religious Centers" Course, had received a task to complete a thematic bibliography, using electronic catalogs of Bulgarian libraries, based on sources included in "Religion. Theology" Main Class №2 of the UDC. They were from "Cultural Heritage" major, "Information Resources of Tourism" major, and "Print Communications" major.

Such online catalogues are available at the web sites of the "St. St. Cyril and Methodius" National Library, all regional libraries, the Central Library of the Bulgarian Academy of Sciences, and some municipal libraries. Students had to select books, periodicals and web resources in Bulgarian and foreign languages.

The main objectives of task were formulated as: 1. Developing students' skills for working with IT resources in electronic catalogue of particular library, for use of electronic databases, for thematic selection of publications, for arrangement of titles under the current State Bulgarian Bibliographic Standard; 2. Developing students' critical thinking and selection skills of scientific works. The task was performed by the full-time students in one academic hour (45 minutes). Students used laptops and tablets, and filled the results in a worksheet. At the end of the exercise the lecturer examined and commented the work.

Students met obstacles in demand in electronic catalogues due to their low digital literacy and lack of experience. Another reason was their insufficient theoretical knowledge on bibliography and religion, which could be compensated with help from the lecturer. Despite the difficulties in drafting the bibliography, it proved to be useful for the training of students as they gained experience, working with library and information resources, and understood their importance in the field of theology.

\section{Searching of publications from digitized periodicals, content analysis and composing of thematic bibliography}

In the 2019/2020 academic year, the students of 3rd grade in "Cultural Heritage" major, attending the "History of Religious Denominations in Bulgaria" Course, had received a task to find publications from Bulgarian periodicals available on line in the "Digital Library" of the "St. St. Cyril and Methodius" National Library.

The project for digitization of literary heritage of the National Library covers manuscripts, early printed books, archival documents, portraits and photographs, graphic and cartographic editions, and Bulgarian newspapers and journals from 1844-1944. A free and open access is provided to the digital copies through the website of the National Library (Didgital library, 2020).

The exercise was conducted with 20 full-time students in two academic hours (90 minutes). It consists of 10 minutes for instruction and demonstration from the lecturer, 45 minutes for self-study of digital databases, 25 minutes for bibliographic description found items, and 10 minutes for discussion of the results. The same task was given to part-time students for self-work, which was used to assess their work in the end of the semester.

Students were directed to process four types of newspapers and magazines: issues of religious institutions ("Novini" (Daily News) and "Vesti" (News) - newspapers of the Bulgarian Orthodox Church, and "Bratstvo" (Brotherhood) - edition of the "White Brotherhood" Religious Society), issues of political parties ("Svobodno slovo" (Free Speech) Newspaper of the Liberal Party), weekly newspapers ("Vestnik na vestnitsite" (Newspaper of the Newspapers) of the Union of the Capital's Journalists), and issues of cultural societies ("Literaturen glas" (Literary Voice) and "Ilustratsia - Svetlina" (Illustration - Light) newspapers). The assignment included a review of the two volumes of those newspapers. The task was to find publications relating to religious events and personalities and for the public presence of religion.

The main teaching goals were formulated as: 1. Developing students' skills for working with DocuWare software, for searching databases, for performing thematic content analysis of articles in periodicals, to make a 
bibliographic description, and to compose a reference list; 2. Shaping students' skills to prepare thematic bibliography; and 3. Formation of students' knowledge for the public presence of religion in society until 1944 and for the religious communities in Bulgaria in that period.

In all 20 reference lists the part-time students included 336 titles, i.e. an average of 17 per student. They covered the period 1897-1944 and several topics: work of religious institutions; biographies of religious leaders; worship places and temples of different religious communities; religious holidays, services, prayers, consecration of buildings and monuments; social status and public manifestation of the clergy. All titles were organized in a bibliographic database in order to prepare a thematic retrospective bibliography on Bulgarian religious heritage.

Students did not impede, dealing neither with the National Library's digital library, nor with DocuWare software. They faced some obstacles in bibliographic description of publications, which requires precise compliance with the State Bulgarian Bibliographic Standard and in content-analysis that should be examined large mass of information in order to select appropriate articles.

\section{Conclusions}

Teaching methods are a dynamic pedagogical category that is influenced by the goals of university education, of interests and motivation of students, and of needs of practice. They are a key factor in building an effective educational process.

The best practices for working with electronic resources described in this research paper are a result of our long-standing work to improve our teaching methods of "Religion" in an academic milieu and had been tested by authors. In addition to the presented methods, they can be combined with interactive methods if this is optimal for the purposes of training.

The results of working with online-based electronic resources show that they are extremely useful in the education of students in the humanities and social sciences, because through them they are able to learn and apply new knowledge in Religion and IT, and to develop their practical skills how to search, select and present information. Overall this could support their future competitiveness in the labour market.

It is of particular importance that web-based resources can be primary source and, at the same time, become a commonly used method in religious education in higher education, combined with specific cultural heritage and bibliography teaching methods.

Subordinated to the principles of "learning by doing" and linking theory with practice, the application of electronic resources in training in religion and religious cultural heritage supports the future professional career of library and information specialists, cultural heritage specialists, experts in print and electronic media, in tourism and museums in the labour market and is a guarantee for improving the work of these institutions in the modern information environment.

Author Contributions: Conceptualization, S.S. and G.N.; Methodology, S.S. and G.N.; Validation, S.S. and G.N.; Formal Analysis, S.S. and G.N.; Investigation, S.S. and G.N.; Resources, S.S. and G.N.; Writing - Original Draft Preparation, S.S. and G.N.; Writing - Review \& Editing, G.N.; Supervision, G.N.; Project Administration, G.N.

Conflicts of Interest: The authors declare no conflict of interest.

\section{References}

Beard, C. M., \& Wilson, J. P. (2006). Experiential learning: a best practice handbook for educators and trainers. Kogan Page.

Chryssides, G. D. (2013). The internet as a resource in the study of religion. In G. D. Chryssides \& R. Geaves (Eds.), The study of religion: an introduction to key ideas and methods (pp. 339-360). Bloomsbury.

Didgital library. (2020). "St. St. Cyril and Methodius” National Library. http://nationallibrary.bg/wp/?page_id=1337

Dobreva, R. (2015). Kulturni politiki v obshtestvenite biblioteki: istoricheski retrospektsii i moderni transformatsii [Cultural policies in public libraries: historical retrospections and modern transformations]. Regional Library.

Gorman, M. (2006). Our enduring values: the librarianship in the 21 st century. Kliment Ohridski University Publishing House.

Jackson, R. (2014). 'Signposts: policy and practice for teaching about religions and non-religious world views in intercultural education. CoE. 
McIlwaine, I. C. (2009). Universal Decimal Classification (UDC). In M. J. Bates \& M. N. Maack (Eds.), Encyclopedia of library and information sciences (3rd ed., pp. 5432-5439). Taylor \& Francis.

Mladenova, M. (2003). Universalanata desetichna klasifikatsia: struktura I metodologia na klasifikatsia [The universal decimal classification: structure and methodology of classification]. Kvazar.

Nazarska, G., \& Shapkalova, S. (2015). Metodika za obuchenieto po religia vav visshite svetski uchilishta [Teaching methods for religious education in the secular universities]. Za bukvite $-\mathrm{O}$ pismeneh.

Wilson, B. R. (1982). Religion in sociological perspective. Oxford University Press.

Zakon za obstestvenite biblioteki [Public libraries act]. 5 June 2009. https://www.lex.bg/laws/ldoc/2135636021

(C) 2020 by the authors. Submitted for possible open access publication under the terms and

conditions of the Creative Commons Attribution (CC BY) license

(http://creativecommons.org/licenses/by/4.0/). 